\title{
Impact of undergraduate research participation in characterization of materials
}

\section{Aschalew Kassu, Carlton Farley III, Jonathan Mills, Anup Sharma, Paul Ruffin}

Aschalew Kassu, Carlton Farley III III, Jonathan Mills, Anup Sharma, Paul Ruffin, "Impact of undergraduate research participation in characterization of materials," Proc. SPIE 10741, Optics Education and Outreach V, 1074106 (14 September 2018); doi: 10.1117/12.2320310

SPIE Event: SPIE Optical Engineering + Applications, 2018, San Diego, California, United States 


\title{
Impact of undergraduate research participation in characterization of materials
}

\author{
Aschalew Kassu ${ }^{*}$, Carlton Farley III ${ }^{\mathrm{b}}$, Jonathan Mills ${ }^{\mathrm{b}}$, Anup Sharma ${ }^{\mathrm{b}}$, Paul Ruffin ${ }^{\mathrm{b}}$ \\ aDepartment of Mechanical, Civil Engineering \& Construction Management \\ Alabama A\&M University, Normal, AL, USA, 35762 \\ ${ }^{b}$ Department of Physics, Chemistry \& Mathematics \\ Alabama A\&M University, Normal, AL, USA, 35762
}

\begin{abstract}
Nowadays, undergraduate research is recognized as an essential component of STEM discipline enhancing students learning outcome. As a result, governmental and non-governmental agencies have been allocating a substantial amount of funding and resources to support undergraduate students through scholarships and research activities. In addition to reinforcing the traditional classroom learning experience and providing the students with hands-on experience early on in their studies, undergraduate research is one of the key motivating factors to pursue graduate education and advance careers in STEM fields. In this paper, the positive impact of mentoring and engaging undergraduate students in paid research activities, and the project outcomes including awards and recognitions received by the students are discussed.
\end{abstract}

Keywords: Undergraduate research, STEM education, undergraduate research funding, mentoring, material characterization.

\section{INTRODUCTION}

The contributions of research and educational funding opportunities provided by government agencies and private companies are key elements of involving graduate and undergraduate students in research activities. The funding plays a vital role in solving the financial constraints of research labs in equipping research laboratories with instruments and supplies and incentives to the students, faculty members and staffs. At the institutional level, Alabama Agricultural and Mechanical (A\&M) University has been graciously providing scholarship opportunities, primarily tuition and boarding, to several undergraduate students attending the university. As part of the strong institutional and faculty members' commitments to secure external funding through grants and contracts, we received a grant from the Department of Homeland Security involving undergraduate research activities. Under this project, several students have been participating in research projects in the area of optical, thermoelectric and electrical characterization of materials. The funding received from the DHS allowed us to support about 15 students majoring in physics, chemistry, construction, mechanical and electrical engineering. The undergraduate students were mainly involved in research activities in the area of optical characterization and studies of thermoelectric and electrical properties of materials, fabrication, and characterization of thermoelectric devices from thin films. The mentoring and research activities created a platform to understand the applications of optics and material science research in STEM fields. In addition to alleviating the financial burden of both the students and the parents, the scholarship opportunities provided, (1) encourages the students to spend more time attending classes, studying, and other academic-related activities on campus than seeking and off-campus employment opportunities, (2) early completion of the coursework and graduating in less than five years, (3) maintain good GPA which will open other scholarship opportunities offered on-campus and off-campus, as well as internship and 'co-op' opportunities which likely opens up full time employment opportunities after graduation, and (4) it provided hands-on experience on research and experimental techniques and prepares them for advanced studies. The next section summarizes a review of literatures on engaging undergraduate students in research and mentoring programs. The results and discussion section of the paper provides the outcomes of the project supported by DHS-Scientific Leadership Award.

*Corresponding author: aschalew.kassu@,aamu.edu

Optics Education and Outreach V, edited by G. Groot Gregory, Proc. of SPIE Vol. 10741, 1074106

(c) 2018 SPIE · CCC code: $0277-786 X / 18 / \$ 18 \cdot$ doi: 10.1117/12.2320310 


\section{LITERATURE REVIEW}

Griffith (2010), studied the relationship between institutional research spending and the likelihood of women and minority students' persistence in undergraduate STEM fields ${ }^{1}$. The findings indicate that institutions with a higher level of research focus and spending as compared with teaching were less likely to have persistence in undergraduate STEM majors and more favorable to students enrolled in graduate level, primarily Ph.D. students. Another interesting observation was such institutions with significant research funding were able to involve their undergraduate students in research, which did not translate to students' retention in STEM fields. According to Xu (2018), the major factor for improving students' learning experience in college persistence of STEM fields and completion of STEM degree is faculty's student advising and engaging them ${ }^{2}$. Earlier research suggests that, for minority students, as compared with student loans, there is a positive association between student persistence and grants. Students receiving grants are more likely to earn their Bachelor's degree as compared with students taking student loans ${ }^{3}$.

Barlow and Villarejo (2004) evaluated the effect of engaging students through educational enrichment programs on the persistence of undergraduate minority students majoring in Biological Sciences at the UC Davis. The research suggested that involving undergraduate students from an underrepresented minority group in research has a positive outcome in improving the likelihood of participating students in earning an undergraduate degree and pursue an advanced degree in STEM $^{4}$.

In his studies on 'learning by research' using the classroom Image Processing and Fiber Optics undergraduate level courses, Costa $(1997,2000)$ indicated that augmenting the classroom lecture with research and active participation of students in experimental works which he called it 'Learning by Research', have a significant impact on building students' research interest, confidence, and motivation for deeper understanding of the principles of science and engineering concepts ${ }^{5,6}$. Such motivation and understanding of the underlying principles of science and engineering also help the students to turn their creative thinking and ideas into the entrepreneurial mindset and product development generating sustainable and income ${ }^{7,8}$.

The key motivating factor to pursue graduate education in STEM discipline and advance research interests in science and engineering is involvement of undergraduate students in research activities ${ }^{9-14}$, encouraging them to present their findings to the scientific communities through poster presentations.

\section{RESULTS AND DISCUSSION}

The undergraduate research opportunities created at Alabama Agricultural and Mechanical University created and improved the channel of communication between the diverse body of undergraduate students majoring in science and engineering and the participating faculty research mentors. Based on the responses to questionnaires completed by the students, overall, the opportunity to engage students in undergraduate paid research and mentoring activities assists the students in achieving their academic and professional goals in their discipline. In compliance with earlier reports, for minority students, as compared with student loans, there is a positive association between student persistence and grants, and students receiving grants are more likely to earn their Bachelor's degree as compared with students taking student loans ${ }^{4}$.

The DHS-SLA scholars co-mentored by the PI, co-PI and other participating professors at Alabama A\&M University were able to conduct research in the areas of Raman spectroscopy of chemicals and adulterants in food, nano-structured chemical sensors, fabrication of nanocomposite films for energy harvesting applications, fabrication of carbon nano-tube-based nanoelectronics devices and integrated circuits, and fabrication and characterization of thermoelectric devices from thin films. This research opportunity produced several high-quality journal articles, conference publications, presentations, and awards. Some of the outcomes of involving undergraduate students in research projects in our lab are summarized below.

- The students mentored under this program had the opportunities to present their research works in several local and national conferences including the annual Emerging Researchers National (ERN) conference in STEM sponsored by the National Science Foundation (NSF) and the American Association for the Advancement of Science (AAAS), the Alabama Academy of Sciences (AAS), the Science and Technology Open House, the annual Alabama A\&M 
University's STEM day, and Magic City Classic STEM Expo. Attending such conferences and presenting posters in such conferences enhanced the students' presentation skills and confidence in public speaking.

- As our institution is one of the HBCUs, our undergraduate research and mentoring program primarily focuses on underrepresented minority STEM students. In line with this goal, the project created opportunities to attend professional and scientific annual conferences such as the annual National Society of Black Physics (NSBP), the National Society of Black Engineers (NSBE), and the BAYA Black Engineer of the Year Award (BEYA) STEM conferences. These conferences focus on education and career-oriented workshops, career fairs, and venues to connect with STEM carrier coaches and mentors for minority students.

- The research activities created a platform for the students to understand optical and materials characterization techniques specific to their major areas of study. To mention a couple of interesting research projects completed by the two students majoring in Construction, which would not have been possible without this mentoring project was the application of Raman spectroscopy in optical characterization of building materials ${ }^{15}$, monitoring rate of hydration cement mortar and other related works specific to the applications optical techniques in the study of construction materials. In addition to studying the thermoelectric and electrical properties of thin films, which is more specific to their major areas, the participating Electrical Engineering majors used Raman spectroscopic technique to characterize the thin films and for detection and identification of nitrates using standoff Raman spectroscopy, adulteration of olive oil, and flour. All the students who were involved in our undergraduate research projects co-authored referred journals and conference proceedings. We believe that this co-authorship of refereed journal publications and conference proceedings by our students involved in undergraduate research projects enhanced their resume and professional competence in their area of specialization and are significant accomplishments of our scholarship and the mentorship program.

- As one of the objectives of the program is to encourage the participating students in securing paid summer research internship programs, the PIs have tried to assist the students in connecting with summer research programs including the Science Undergraduate Laboratory Internships (SULI) program at the Department of Energy (DOE) National Labs, the Department of Defense (DOE) labs, and the NSF-REU programs. In this regard, almost all the students in our program were able to secure summer internship programs at National Labs (Brookhaven and Oakridge National Labs), NASA, Northrop Grumman Corporation, Apple, REU programs at universities across the nation, and co-ops at the Department of Defense, Aviation and Missile Research, Development, and Engineering Center (AMRDEC). The students who completed their internship at Oakridge National Lab and co-op at Northrop Grumman Corporation and AMRDEC got fulltime job offers, though the student offered by Oakridge decided to accept another offer from a private company.

- Involving students in research activities enhanced students' potential career choice in STEM-related fields. In May 2018, five of the DHS-scholarship recipients who participated in the research programs received their Bachelor's degree in Construction and Electrical Engineering. Two of the graduates joined a federal government agency, where they have been working as co-op engineers with AMRDEC as Electromagnetic, Test, and Instrumentation Engineer; and Prototype Integration Facility Engineer. Similarly, one other student also joined the same agency (Northrop Grumman) where she has been interning with. These students confirmed that their internship and co-ops were motivated by their participation in undergraduate research projects early on in their freshman and sophomore years, which ultimately shaped their search for summer internships and co-op programs, which landed them into a full-time employment position.

- The students involved in STEM undergraduate research at Alabama A\&M have also shown promising interest in research and pursue graduate studies. So far, out of the four students who graduated last year three of them are currently pursuing graduate study, one in a Ph.D. program in Physics at Tulane University, and the other two are enrolled in MS program in Physics at Alabama A\&M University, and Pubic Health (Epidemiology) in Boston University. Based on their response to the survey questionnaire distributed to the participants, their decision to pursue graduate studies is influenced by their participation in undergraduate research. The fourth graduate decided to accept a federal government job offered by the U.S. Navy, as a Software Surveillance Engineer with Naval Surface Warfare Center (NSWC).

- The other significant success of this project is that some of the students mentored in the program have received awards and recognition at the local and national levels. Some of the awards include best research poster presentation award at the Alabama Academy of Sciences, and at the Alabama A\&M's Annual STEM Day poster competition. More recently, the national Career Communications Group, Inc. selected one of our student as the Women of Color Research Award winner and recognized her during the $22^{\text {nd }}$ Annual Women of Color Awards STEM Conference held in Detroit, MI on October 7, 2017. 
- Most of DHS-scholars have completed the project related course called 'Fundamentals of Nanotechnology' developed and taught by the co-PI of the project. The course includes materials related to Raman spectroscopy and other sensing techniques used by the students and faculty researchers for detecting explosives-related chemicals. Periodically, some of the lectures were given by other research mentors to prepare students in their areas of research. The topics covered by participating faculty mentors include an introduction to conventional Raman and surface-enhanced Raman spectroscopy techniques, fabrication of carbon nanotube-based nano-electronics devices and integrated circuits, nanostructured chemical sensors, and fabrication and characterization of thermoelectric devices from thin films.

\section{CONCLUSIONS}

This article presents the impacts of undergraduate funding including monthly stipends during the fall and spring semesters and tuition support on students' research interest and accomplishments, long-term career goals, and pursuing graduate studies is reported. The program was initiated in 2014 with a generous support from the Department of Homeland SecurityScientific Leadership Award (DHS-SLA). Initially, the program recruited students majoring in Electrical Engineering (EE), Physics, Construction, and Chemistry. The students were assigned to work in different research projects under the supervision of the participating faculty members from the departments of Physics, Construction, and EE. The authors of this article believe that mentoring and engaging students in undergraduate research activities early on during their freshman and sophomore years will certainly familiarize the students in research projects, enhances their resume and academic credentials, build self-confidence and interest in exploring research ideas, formulate research procedures and be the next generation of engineers and scientists. In addition to alleviating the financial burden on the students and their parents might have, the project provided several opportunities for the students. Based on the outcomes we have so far and from the survey responses received from the participating undergraduate students mentored under our program, overall, the students involved in ours undergraduate STEM research program have shown promising interest in research and graduate studies. Some of them have already joined graduate schools and received national awards and recognitions under outstanding research category.

\section{ACKNOWLEDGMENTS}

This work is supported by the Department of Homeland Security-Scientific Leadership Award, under Grant Nos. DHSSLA 2014-ST-062-000060, and 2014-ST-062-00060-02.

\section{REFERENCES}

[1] Griffith, A. L. "Persistence of women and minorities in STEM field majors: Is it the school that matters?" http://digitalcommons.ilr.cornell.edu/workingpapers/122/ Retrieved July 15, 2018.

[2] Xu, Y. J. "The experience and persistence of college students in STEM majors," Journal of College Student Retention: Research, Theory \& Practice 19(4), 413-432 (2018).

[3] Swail, W. S., Redd, K. E., Perna, L. W. "Retaining minority students in higher education: A framework for success," ASHE-ERIC Higher Education Report, 30(2), Wiley Periodicals, Inc., NJ, USA, (2003).

[4] Barlow, A. E. L., Villarejo, M. "Making a difference for minorities: Evaluation of an educational enrichment program," Journal of Research in Science Teaching 41(9), 861-881 (2004).

[5] Costa, M. F. M. "New developments of the project Learning by Research," Proc. SPIE 3831, Sixth International Conference on Education and Training in Optics and Photonics, (2000).

[6] Costa, M. F. M. "Teaching by research at undergraduate schools: an experience," Proc. SPIE 3190, Fifth International Topical Meeting on Education and Training in Optics, (1997).

[7] Zhan, W., Wang, J., Vanajakumari, M., Johnson, M. "Creating a high impact learning environment for engineering technology students," Advances in Engineering Education, 1-23 (2018).

[8] Zhan, W., Wang, J., Vanajakumari, M., "High impact activities to improve student learning," Proceedings of the American Society for Engineering Education Annual Conference, (2013). 
[9] Plotkowski, P. D., Joseph, J. "Enhancing graduation rates through high impact activities: Experiential learning, engagement, mentoring, and scholarships," Proceedings of the American Society for Engineering Education Annual Conference, 22.618.1 (2011).

[10] Hathaway, R. S., Nagda, B. A., Gregerman, S. R. "The relationship of undergraduate research participation to graduate and professional education pursuit: An empirical study," Journal of College Student Development 43(5), $1-18$ (2002).

[11] Hunter, A. B., Laursen, S. L., Seymour, E. "Becoming a scientist: The role of undergraduate research in students' cognitive, personal, and professional development," Science Education 91, 36-74 (2006).

[12] Eagan, M. K., Hurtado, S., Chang, M. J., Garcia, G. A., Herrera, F. A., Garibay, J. C. "Making a difference in science education: The impact of undergraduate research programs," American Educational Research Journal 50(4), 683-713 (2013).

[13] Seymour, E., Hunter, A. B., Laursen, S. L., Deantoni, T. "Establishing the benefits of research experiences for undergraduates in the sciences: First findings from a three-year study," Science Education 88, 493-534 (2004).

[14] Price, D. V., Davis, R. J. "Institutional grants and baccalaureate degree attainment," National Association of Student Financial Aid Administrators (NASFAA), Washington, DC, June 2006. https://files.eric.ed.gov/fulltext/ED543358.pdf, Accessed on July 14, 2018

[15] Kassu, A., Walker, L., Sanders, R., Farley, C., Mills, J., Sharma, A., "Nondestructive spectroscopic characterization of building materials," Proc. SPIE, Nondestructive Characterization and Monitoring of Advanced Materials, Aerospace, and Civil Infrastructure, and Transportation XI, 10169, 101692V-1 (2017). 